\title{
Proteolysis, lipolysis, volatile compounds, texture, and flavor of Hispánico cheese made using frozen ewe milk curds pressed for different times
}

\author{
A. Picon, P. Gaya, E. Fernández-García, A. Rivas-Cañedo, M. Ávila, and M. Nuñez ${ }^{1}$ \\ Departamento de Tecnología de Alimentos, Instituto Nacional de Investigación y Tecnología Agraria y Alimentaria (INIA) Madrid, 28040 Spain
}

\begin{abstract}
Hispánico cheese is manufactured in Spain from a mixture of cow and ewe milk. Production of ewe milk varies throughout the year, with a peak in spring and a valley in summer and autumn. To overcome this seasonal shortage, curd from spring ewe milk may be frozen and used for cheese manufacture some months later. In the present work, ewe milk curds pressed for 15,60 , or $120 \mathrm{~min}$ were held at $-24^{\circ} \mathrm{C}$ for $4 \mathrm{mo}$, thawed, cut to 1-mm pieces, and mixed with fresh cow milk curd for the manufacture of experimental Hispánico cheeses. Control cheese was made from a mixture of pasteurized cow and ewe milk in the same (80:20) proportion. Cheeses, made in duplicate experiments, were analyzed throughout a $60-\mathrm{d}$ ripening period. No significant differences between cheeses were found for lactic acid bacteria counts, dry matter content, hydrophilic peptides, 47 out of 68 volatile compounds, texture, and flavor characteristics. On the other hand, differences of minor practical significance between experimental and control cheeses, unrelated to the use of frozen ewe milk curd or the pressing time of ewe milk curd, were found for $\mathrm{pH}$ value, aminopeptidase activity, proteolysis, hydrophobic peptides, free amino acids, free fatty acids, and the remaining 21 volatile compounds. It may be concluded that the use of frozen ewe milk curd in the manufacture of Hispánico cheese does not alter its main characteristics.
\end{abstract}

Key words: frozen curd, ewe milk, Hispánico cheese, pressing time

\section{INTRODUCTION}

Hispánico cheese is a semi-hard Spanish variety made throughout the year from a mixture of cow and ewe milks. It stands as a representative of the varieties made from a mixture of milks from more than one species, which account for more than $50 \%$ of the cheese

Received December 29, 2009

Accepted March 21, 2010.

${ }^{1}$ Corresponding author: nunez@inia.es produced in Spain. Maintaining the desirable 80:20 proportion of cow and ewe milks in the manufacture of Hispánico cheese may become difficult because of the seasonality in ewe milk production, with a peak in spring months and a valley in summer and autumn. To overcome this shortage during summer and autumn, curd from spring ewe milk might be frozen and some months later, after thawing, mixed with fresh cow milk curd and made into Hispánico cheese.

Ewe milk curd or cheeses have been frozen and ripened after thawing with the aim of overcoming the seasonal shortage in ewe milk production, with variable results. Blocks of drained unsalted curd from ewe milk, mixed with $10 \%$ goat milk, were frozen at $-20^{\circ} \mathrm{C}$ and, after 1,2 , or 6 mo of storage, thawed, salted, packaged, and ripened to obtain Teleme cheese. Experimental cheeses had a higher soluble $\mathrm{N}$ content than control cheese and a crumbly texture, but no flavor defects (Alichanidis et al., 1981). Similarly, 2-d-old salted ewe milk cheese was frozen at $-20^{\circ} \mathrm{C}$ for $4 \mathrm{mo}$ and, after thawing, ripened for 3 mo. Proteolysis was more intense, bacterial counts and water activity were lower, texture was softer, and crevices were more abundant than in control cheese, but there were no differences in sensory flavor characteristics (Fontecha et al., 1994, 1996). Also, pressed ewe milk curd was packed, frozen at various temperatures, held at $-23^{\circ} \mathrm{C}$ for up to $4 \mathrm{mo}$, thawed, salted, and ripened for 2 mo to obtain a semi-hard cheese. The freezing, packaging, and storage conditions of ewe milk curd influenced characteristics of experimental cheeses, which exhibited higher levels of soluble N, a softer texture, and a milder flavor than control cheese made from fresh curd (Sendra et al., 1999, 2002). Fully ripened 3-mo-old Los Pedroches ewe milk cheese was held at $-20^{\circ} \mathrm{C}$ for up to 9 mo to prevent over ripening. Proteolysis proceeded during frozen storage, although at a slow rate, whereas the $\mathrm{pH}$ value rose and the lactic acid content decreased. A less creamy and rather grainy texture developed after 3 mo, but cheese flavor characteristics remained unchanged for 6 mo (Tejada et al., 2000, 2002).

Research reported so far on frozen ewe milk curd or cheeses was based on freezing the product molded to 
its final size and shape to stop, for a certain period, the biochemical changes occurring during manufacture or ripening. Afterward, curds or cheeses were thawed and biochemical changes proceeded. A novel approach is considered in the present work. Ewe milk curd, frozen after pressing for different times, was thawed, cut into small pieces, and added to a cheese vat containing fresh cow milk curd still in its own whey, to manufacture Hispánico cheese. This new procedure may be economically advantageous compared with freezing whole cheeses, because just a small (approximately 20\%) portion of the final product is frozen. We observed in preliminary trials that curd pressing for $3 \mathrm{~h}$ or longer yielded ripe cheese with an abnormal nonhomogeneous visual appearance. For this reason, pressing times of 15,60 , and 120 min were compared in the present work. Ewe milk curd pressing time; that is, curd age at freezing, as well as the freezing and thawing steps might influence lactic acid bacteria (LAB) lysis and enzyme release into the surrounding substrate, and thereafter cheese characteristics. Experimental cheeses were monitored throughout ripening, and compared with control cheese made from a mixture of pasteurized cow and ewe milk. Bacterial counts, enzymatic activities, proteolysis, lipolysis, volatile compounds, and texture and flavor characteristics of Hispánico cheeses are here reported.

\section{MATERIALS AND METHODS}

\section{Curd Manufacture}

In duplicate trials carried out on different days, ewe milk $(50 \mathrm{~L}, 7.58 \%$ fat, $5.76 \%$ protein, pasteurized at $75^{\circ} \mathrm{C}$ for $\left.15 \mathrm{~s}\right)$ was heated to $32^{\circ} \mathrm{C}, \mathrm{CaCl}_{2}(50 \mathrm{~mL}$ of a $10 \%$ solution) was added, and commercial (Rhodia, Dangé Saint-Romain, France) lactic cultures MA 016, consisting of Lactococcus lactis strains, and TA 052, consisting of Streptococcus thermophilus strains, grown in sterile milk, were inoculated $(500$ and $100 \mathrm{~mL}$, respectively). Rennet (10 mL Maxiren, 1:15,000 strength, Gist Brocades, Delft, the Netherlands) was added to milk 20 min later. After $40 \mathrm{~min}$, the curds were cut into 5 -mm cubes and held at $35^{\circ} \mathrm{C}$ for $15 \mathrm{~min}$. Once the whey was drained off, the curds were distributed into cylindrical molds, pressed for 15,60 , or $120 \mathrm{~min}$, cut into 2-cm thick slices, and vacuum packed in BB325 plastic film bags (Cryovac, Barcelona, Spain). Curd slices were immersed in an ice-water mixture at $0^{\circ} \mathrm{C}$ for $15 \mathrm{~min}$, and afterward frozen in a multiple plate-freezer at $-52^{\circ} \mathrm{C}$. When a temperature of $-24^{\circ} \mathrm{C}$ was reached at the core of the slice (approximately $55 \mathrm{~min}$ ), the curds were transferred to a freezer cabinet and held at $-24^{\circ} \mathrm{C}$ for $4 \mathrm{mo}$.

\section{Cheese Manufacture}

Control Hispánico cheese was made in duplicate trials carried out on different days from a mixture of $64 \mathrm{~L}$ of cow milk (3.42\% fat, $3.15 \%$ protein) and $16 \mathrm{~L}$ of ewe milk ( $7.71 \%$ fat, $5.85 \%$ protein), pasteurized at $75^{\circ} \mathrm{C}$ for $15 \mathrm{~s}$. Addition of $\mathrm{CaCl}_{2}$, lactic cultures, and rennet was in the same proportions as above described. After 40 min, the curds were cut into 5 -mm cubes and scalded at $38^{\circ} \mathrm{C}$ for $15 \mathrm{~min}$. Once the whey was drained off, the curds were distributed into cylindrical molds. Five cheeses, approximately $2 \mathrm{~kg}$ each, were pressed overnight at $20^{\circ} \mathrm{C}$ and $1.5 \mathrm{~kg} / \mathrm{cm}^{2}$ pressure, salted for $24 \mathrm{~h}$ at $12^{\circ} \mathrm{C}$ in $160 \mathrm{~g} \mathrm{NaCl} / \mathrm{L}$ brine, and ripened at $12^{\circ} \mathrm{C}$ and $85 \%$ relative humidity for $60 \mathrm{~d}$. On d 7 , cheeses were coated with 2 layers of pimaricine-containing polyvinyl acetate (Fungirol, Laboratorios Arroyo, Santander, Spain).

On each of the $2 \mathrm{~d}$ of control cheese manufacture, 3 vats of experimental cheeses were made, using frozen ewe milk curd of the 3 different pressing times. In each vat, $64 \mathrm{~L}$ of pasteurized $\left(75^{\circ} \mathrm{C}\right.$ for $\left.15 \mathrm{~s}\right)$ cow milk were coagulated as described above. After $40 \mathrm{~min}$, the curds were cut into 5 - $\mathrm{mm}$ cubes and scalded at $38^{\circ} \mathrm{C}$ for 10 min. At that time, ewe milk curd thawed overnight at $4^{\circ} \mathrm{C}$ was cut into $1-\mathrm{mm}$ pieces and added to the vat, in an amount equivalent to $16 \mathrm{~L}$ of the milk from which it had been obtained. The mixture of curds was scalded for $5 \mathrm{~min}$ at $38^{\circ} \mathrm{C}$, and the whey was drained off. The rest of manufacture and the ripening process were as above described for control cheese.

\section{Microbiological Analysis and Aminopeptidase Activity}

Counts of LAB were determined in duplicate on plate count agar (Liofilchem, Roseto, Italy) with $0.1 \%$ skim milk (Biolife, Milano, Italy) added. Previous trials had shown that lactococci were the only colony formers on plates incubated aerobically for $24 \mathrm{~h}$ at $30^{\circ} \mathrm{C}$ and thermophilic streptococci on plates incubated aerobically for $24 \mathrm{~h}$ at $40^{\circ} \mathrm{C}$.

Aminopeptidase activity released into the cheese was measured on duplicate samples of an extract obtained by homogenizing $10 \mathrm{~g}$ of cheese with $20 \mathrm{~mL}$ of $10 \mathrm{mM}$ sodium phosphate buffer, $\mathrm{pH} 7$, at $20^{\circ} \mathrm{C}$ for $2 \mathrm{~min}$ in an Ultraturrax T18 apparatus (IKA Werke GmbH, Staufen, Germany), followed by centrifuging $(10,000 \times$ $g, 15 \mathrm{~min}, 4^{\circ} \mathrm{C}$ ) and filtering through Whatman No. 2 paper. Lysine $p$-nitroanilide (Lys- $\boldsymbol{p}$-NA) and leucine $p$-nitroanilide (Leu- $p$-NA) were used as substrates. One activity unit corresponds to the activity of enzyme (s) producing 1 nanomole of $p$-nitroaniline per minute per gram of cheese. 


\section{Chemical Determinations}

Cheese $\mathrm{pH}$ was measured in duplicate by means of a Crison pH meter (model GPL 22, Crison Instruments, Barcelona, Spain) using a Crison penetration electrode (model 52-3.2). Dry matter content was determined in triplicate after drying to constant weight in a vacuum oven at $100^{\circ} \mathrm{C}$.

Cheese overall proteolysis was determined on duplicate samples by the o-phthaldialdehyde (OPA) test, based on the reaction of released $\alpha$-amino groups with this compound and with $\beta$-mercaptoethanol to form an adduct that absorbs strongly at $340 \mathrm{~nm}$ (Church et al., 1983).

Hydrophilic and hydrophobic peptides in the watersoluble fraction of cheese were determined on duplicate samples by reverse phase-HPLC using a Beckman System Gold chromatograph (Beckman Instruments España SA, Madrid, Spain) equipped with a diode array detector module 168, with detection wavelength at $214 \mathrm{~nm}$, as described previously (Lau et al., 1991). Peaks with retention times from 8.5 to 14.6 min were considered to correspond to hydrophilic peptides and those with retention times from 14.6 to $20.5 \mathrm{~min}$ to hydrophobic peptides. Results were expressed as units of chromatogram area per milligram of cheese dry matter.

Free amino acids (FAA) were extracted from duplicate samples (Krause et al., 1995) and individual amino acids determined by reverse phase-HPLC using a Beckman System Gold chromatograph, after derivatization with 6-aminoquinolyl-N-hydroxysuccinimidyl carbamate. Results were expressed as milligrams per kilogram of cheese dry matter.

Free fatty acids were extracted from duplicate samples using a solid-phase extraction technique, with pentanoic, nonanoic, and heptadecanoic acids added as internal standards. Acetic and propionic acid and FFA from butyric $\left(\mathrm{C}_{4: 0}\right)$ to linoleic acid $\left(\mathrm{C}_{18: 2}\right)$ were separated, identified, and quantified as described previously (De Jong and Badings, 1990; Fernández-García et al., 2006), using a gas chromatograph (HP6890, Agilent, Palo Alto, CA) equipped with a split/splitless injector, a 30-m-long, 0.32-mm-i.d., 0.25- $\mu \mathrm{m}$-film thickness FFAP column (Agilent), a flame-ionization detector, and an automatic sampler (HP7683, Agilent). Eleven standard solutions of fatty acids were used for the calculation of calibration curves.

Volatile compounds were analyzed as described previously (Garde et al., 2003), using an automatic dynamic headspace apparatus (Purge and Trap, HP 7695, Hewlett-Packard, Palo Alto, CA) connected to a GC-MS (HP 6890 - MSD HP 5973, Hewlett-Packard) equipped with a 60 -m-long, 0.25 -mm-i.d., 0.5 - $\mu \mathrm{m}$-film thickness capillary column (Innowax, Agilent). Duplicate 10-g cheese samples were homogenized in an analytical grinder (IKA, Labortechnik, Staufen, Germany), with $20 \mathrm{~g}$ of $\mathrm{Na}_{2} \mathrm{SO}_{4}$ and $50 \mu \mathrm{L}$ of an aqueous solution containing $0.5 \mathrm{mg} / \mathrm{mL}$ cyclohexanone as internal standard. An aliquot $(2 \mathrm{~g})$ of the mixture was subjected to helium purge in a $25-\mathrm{mL}$ glass sparger (Schmidlin Co., Neuheim, Switzerland) at $50^{\circ} \mathrm{C}$ for $15 \mathrm{~min}$, with 10 min of previous equilibrium. The analytical procedure and the identification and relative quantification of volatile compounds were carried out as described previously (Carbonell et al., 2002), by using selected ions. Relative abundances of compounds were expressed as percentages of their peak areas on the cyclohexanone peak area.

\section{Instrumental Texture Determinations}

Fracturability (breaking force, N), hardness (work after $75 \%$ compression, J), and elasticity (apparent elastic module, $\mathrm{N} / \mathrm{mm}^{2}$ ) were calculated from the compression curves (6 determinations on each cheese) obtained using an Instron Compression Tester 4301 (Instron, High Wycombe, UK) as described previously (Gaya et al., 1990).

\section{Sensory Evaluation}

Fourteen trained panelists evaluated the cheeses from each of the 2 cheesemaking trials at 15, 30, and $60 \mathrm{~d}$ of ripening for flavor quality, flavor intensity, and flavor attributes "acid," "bitter," "salty," "sweet," and "umami" on a 0 to 10 scale, using a horizontal line anchored in the middle and at both ends (Garde et al., 2006). After removing the rind, cheeses were cut in representative triangular slices ( 15 to $20 \mathrm{~g}$ ), which were held for $2 \mathrm{~h}$ at 20 to $22^{\circ} \mathrm{C}$ before sensory evaluation. Four cheeses per session (3 experimental and 1 control, manufactured on the same day), coded with random 3-digit numbers, were randomly presented to panelists in 6 sessions $(2$ cheese making trials $\times 3$ ripening times). Bread and water were used as rinsing agents between cheeses.

\section{Statistical Analysis}

Statistical treatment of data was performed by means of SPSS Win 8.0 program (SPSS Inc., Chicago, IL). Multifactor ANOVA were carried out considering cheese type (3 experimental cheeses and 1 control cheese) and cheese age as main effects. In addition, means of the different variables for the 4 cheese types were compared using Tukey's test, the significance being assigned at $P$ $<0.05$. 
Table 1. Aminopeptidase activity during ripening of experimental Hispánico cheeses manufactured by mixing fresh cow milk curd (80\%) with frozen ewe milk curd (20\%) pressed for 15, 60, or $120 \mathrm{~min}$, and control cheese made from a mixture of cow and ewe milk

\begin{tabular}{|c|c|c|c|c|c|}
\hline $\begin{array}{l}\text { Aminopeptidase } \\
\text { activity }^{1}\end{array}$ & Age, d & \multicolumn{3}{|c|}{ Experimental cheese ( $20 \%$ frozen ewe milk curd) } & $\begin{array}{l}\text { Control } \\
\text { cheese }\end{array}$ \\
\hline \multirow[t]{5}{*}{ Lys- $p$-NA } & 1 & $1.08 \pm 0.06^{\mathrm{b}}$ & $0.95 \pm 0.03^{\mathrm{c}}$ & $1.12 \pm 0.04^{\mathrm{b}}$ & $1.32 \pm 0.09^{\mathrm{a}}$ \\
\hline & 7 & $1.18 \pm 0.16^{\mathrm{bc}}$ & $1.37 \pm 0.07^{\mathrm{a}}$ & $1.28 \pm 0.03^{\mathrm{ab}}$ & $1.11 \pm 0.04^{\mathrm{c}}$ \\
\hline & 15 & $1.12 \pm 0.03^{\mathrm{a}}$ & $1.00 \pm 0.03^{\mathrm{bc}}$ & $0.90 \pm 0.03^{\mathrm{c}}$ & $1.05 \pm 0.04^{\mathrm{ab}}$ \\
\hline & 30 & $1.75 \pm 0.15^{\mathrm{a}}$ & $1.73 \pm 0.18^{\mathrm{a}}$ & $1.71 \pm 0.12^{\mathrm{a}}$ & $1.53 \pm 0.05^{\mathrm{b}}$ \\
\hline & 60 & $1.82 \pm 0.06^{\mathrm{b}}$ & $1.62 \pm 0.07^{\mathrm{c}}$ & $1.73 \pm 0.05^{\mathrm{b}}$ & $2.10 \pm 0.11^{\mathrm{a}}$ \\
\hline \multirow{3}{*}{ Leu- $p$-NA } & 15 & $1.50 \pm 0.03^{\mathrm{a}}$ & $1.24 \pm 0.08^{\mathrm{b}}$ & $1.29 \pm 0.07^{\mathrm{b}}$ & $1.21 \pm 0.25^{\mathrm{b}}$ \\
\hline & 30 & $2.12 \pm 0.29^{\mathrm{b}}$ & $2.24 \pm 0.04^{\mathrm{b}}$ & $2.32 \pm 0.09^{\mathrm{b}}$ & $2.55 \pm 0.14^{\mathrm{a}}$ \\
\hline & 60 & $3.19 \pm 0.15^{\mathrm{b}}$ & $3.03 \pm 0.17^{\mathrm{b}}$ & $3.36 \pm 0.18^{\mathrm{b}}$ & $3.70 \pm 0.12^{\mathrm{a}}$ \\
\hline
\end{tabular}

${ }^{\mathrm{a}-\mathrm{c}}$ Means in the same row with different superscripts differ $(P<0.05)$.

${ }^{1}$ Mean $\pm \mathrm{SE}(\mathrm{n}=4)$ of duplicate determinations in 2 cheese-making experiments. Aminopeptidase activity is expressed as nanomoles of $p$ nitroaniline (NA) released per minute per gram of cheese.

\section{RESULTS AND DISCUSSION}

\section{LAB and Aminopeptidase Activity}

Counts of mesophilic LAB remained at levels $>9.5$ $\log \mathrm{cfu} / \mathrm{g}$ (data not shown) during the 60-d ripening period, with no significant differences between cheeses. Similarly, counts of thermophilic LAB were at levels $>8.5 \mathrm{log} \mathrm{cfu} / \mathrm{g}$ (data not shown) throughout ripening, with minor differences between cheeses. Freezing and thawing of ewe milk curd before mixing with cow milk curd had a negligible ffect on LAB counts of 1-d-old cheeses. This may appear in contradiction with the decline in LAB counts, close to $1 \log$ unit, reported for Teleme curd frozen for $2 \mathrm{mo}$ at $-20^{\circ} \mathrm{C}$, and close to $2 \log$ units after 6 mo of frozen storage (Alichanidis et al. 1981). Also, lower LAB counts in experimental than in control cheeses, the difference exceeding 1 log unit, were recorded during ripening when unsalted ewe milk cheeses were frozen on d 2 (Fontecha et al., 1994). To understand our results, it must be taken into account that experimental cheeses contained only $20 \%$ frozen ewe milk curd (the rest was fresh cow milk curd), and that $24 \mathrm{~h}$ elapsed between the addition of thawed ewe milk curd to the cheese vat and the microbiological analysis on d 1. Presumably, LAB growth would yield higher counts immediately before freezing in curd pressed for 120 min than in curd pressed for $15 \mathrm{~min}$, but after freezing and thawing, the effect of pressing time on LAB counts in 1-d-old experimental cheeses was nonsignificant for the reasons stated above.

Most LAB enzymes are located in the interior of the cell. An increase of starter LAB lysis could favor access of enzymes to their substrates and the development of cheese flavor (Morgan et al., 1997; Garde et al., 2002a). In the present work, aminopeptidase activity (Table 1) increased during the 60-d ripening period in all cheeses, up to 1.7-fold with Lys- $p$-NA as substrate, and up to 2.6 -fold with Leu- $p$-NA. Differences between cheeses in the rate of release of aminopeptidases into the cheese matrix were of limited practical significance (Table 1), and could not be attributed to the addition of frozen ewe milk curd. The pattern of release did not follow a clear trend when related to pressing time, in agreement with LAB counts, and were at similar levels in all cheeses. Values recorded in the present work with Lys- $p$-NA as substrate were lower throughout ripening, and those obtained with Leu-p-NA higher than the respective values reported for control Hispánico cheese (Garde et al., 2003).

\section{DM Content, $\mathrm{pH}$, and Proteolysis}

Dry matter content (Table 2) increased gradually during ripening in all cheeses because of moisture loss, with no significant $(P<0.05)$ influence of the addition of ewe milk curd or curd pressing time. The lower moisture content reported for Teleme cheese frozen before salting and then thawed compared with control cheese was attributed to its lower water-holding capability, probably because of structural changes in the casein micelle (Alichanidis et al., 1981).

Cheese $\mathrm{pH}$ values showed minor differences between cheeses, unrelated to the addition of frozen ewe milk curd or to curd pressing time (Table 2). Higher $\mathrm{pH}$ values were observed in Teleme cheese frozen before salting, which were ascribed to its lower LAB counts, up to 3 log units less than in control cheese (Alichanidis et al., 1981). Similarly, higher $\mathrm{pH}$ values were found for ewe milk cheese that had been frozen on $d 2$ than for control cheese, during the first month of ripening (Fontecha et al., 1994).

Overall proteolysis as determined by the OPA test, which detects released $\alpha$-amino groups, increased with 
Table 2. Dry matter content, $\mathrm{pH}$ value, and overall proteolysis during ripening of experimental Hispánico cheeses manufactured by mixing fresh cow milk curd (80\%) with frozen ewe milk curd (20\%) pressed for 15, 60, or 120 min, and control cheese made from a mixture of cow and ewe milk

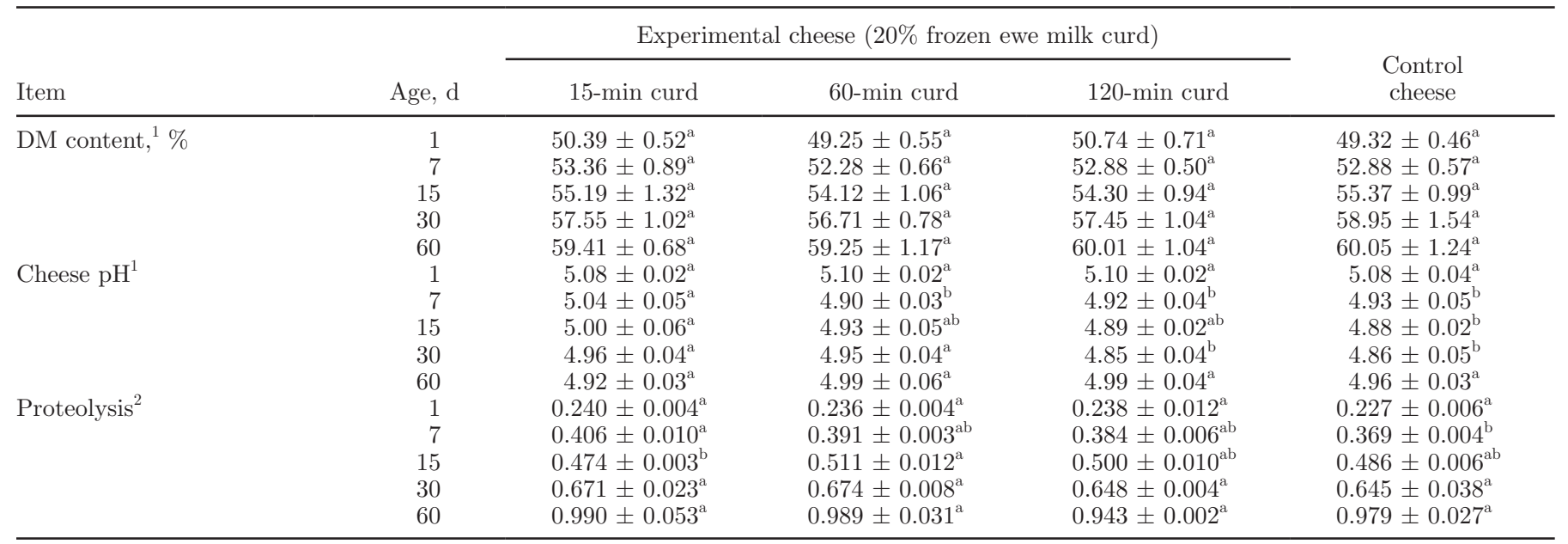

\footnotetext{
${ }^{\mathrm{a}, \mathrm{b}}$ Means in the same row with different superscripts differ $(P<0.05)$.

${ }^{1}$ Mean $\pm \mathrm{SE}(\mathrm{n}=6)$ of triplicate determinations in 2 cheese-making experiments.

${ }^{2}$ Mean \pm SE $(n=4)$ of duplicate determinations in 2 cheese-making experiments. Proteolysis (o-phthaldialdehyde index) is expressed as absorbance at $340 \mathrm{~nm}$.
}

age (Table 2), approximately 4-fold from d 1 to d 60, in experimental and control cheeses. Proteolysis levels found in the present work for 60 -d-old cheeses were similar to the 0.94 value reported for 50-d-old control Hispánico cheese (Garde et al., 2003). Proteolysis values of experimental and control cheeses were similar (Table 2), partly because of their similar aminopeptidase activity (Table 1). An increase in aminopeptidase activity does not imply a higher proteolysis value. Thus, 100-fold differences in aminopeptidase activity between experimental Hispánico cheese made using a bacteriocin-producing culture and control cheese yielded just 2.4-fold increases in overall proteolysis (Garde et al., 2002b). Higher levels of $12 \%$ TCA-soluble N were reported for Teleme cheese frozen before salting, a fact attributed to the enhancement of proteolysis by changes in the structure of frozen curd (Alichanidis et al., 1981). Also, amino $\mathrm{N}$ level of 90-d-old ewe milk cheese frozen on d 2 more than doubled that of control cheese (Fontecha et al., 1994), and phosphotungstic acid-soluble $\mathrm{N}$ reached significantly higher levels during ripening of ewe milk cheese frozen before salting than in the respective control cheese (Sendra et al., 1999). However, the extent of proteolysis was slightly lower in Cabrales cheese, a blue-veined variety, when frozen at $-20^{\circ} \mathrm{C}$ for up to 8 mo before ripening compared with control cheese (Alonso et al., 1987).

\section{Peptides and FAA}

Hydrophilic peptides accumulated during ripening of experimental and control cheeses, with no significant
$(P<0.05)$ differences between cheeses, and increased up to 2.2-fold from d 1 to d 60 (Table 3). Similarly, levels of hydrophobic peptides increased during ripening of all cheeses, up to 4.9-fold, with differences being of limited practical significance. Higher levels of soluble polypeptides were found during late ripening of ewe milk cheese frozen on $\mathrm{d} 2$ than in the respective control cheese (Fontecha et al., 1994), but this was not the case for oligopeptides. Levels of hydrophilic and hydrophobic peptides (Table 4) were similar to those recorded for control Hispánico cheese by Garde et al. (2002b), but levels of hydrophilic peptides were lower and those of hydrophobic peptides higher than in experimental Hispánico cheese made using a bacteriocin-producing culture. The ratio of hydrophobic peptides:hydrophilic peptides, suggested as an index of bitterness (Lau et al., 1991), has been shown to significantly correlate with the sensory perception of bitter taste (Gómez et al., 1997). In the present work, it ranged from 0.48 to 0.51 at the end of the ripening period, in agreement with the 0.48 value found for control 50-d-old Hispánico cheese (Garde et al., 2002b).

Total FAA increased as cheeses aged. Levels on d 60 were close to those reported for control 50-d-old Hispánico cheese (Garde et al., 2002b). From d 30 to 60 , higher levels of total FAA were recorded in cheeses containing frozen ewe milk curd pressed for 15 or 60 min than in the rest (Table 3). During the first 2 mo of ripening, total FAA in Teleme cheese frozen before salting more than doubled the respective values in control cheese (Alichanidis et al., 1981). Free AA usually 
Table 3. Hydrophilic and hydrophobic peptides, determined at $280 \mathrm{~nm}$, and total free amino acids during ripening of experimental Hispánico cheeses manufactured by mixing fresh cow milk curd (80\%) with frozen ewe milk curd (20\%) pressed for 15 , 60 , or 120 min, and control cheese made from a mixture of cow and ewe milk ${ }^{1}$

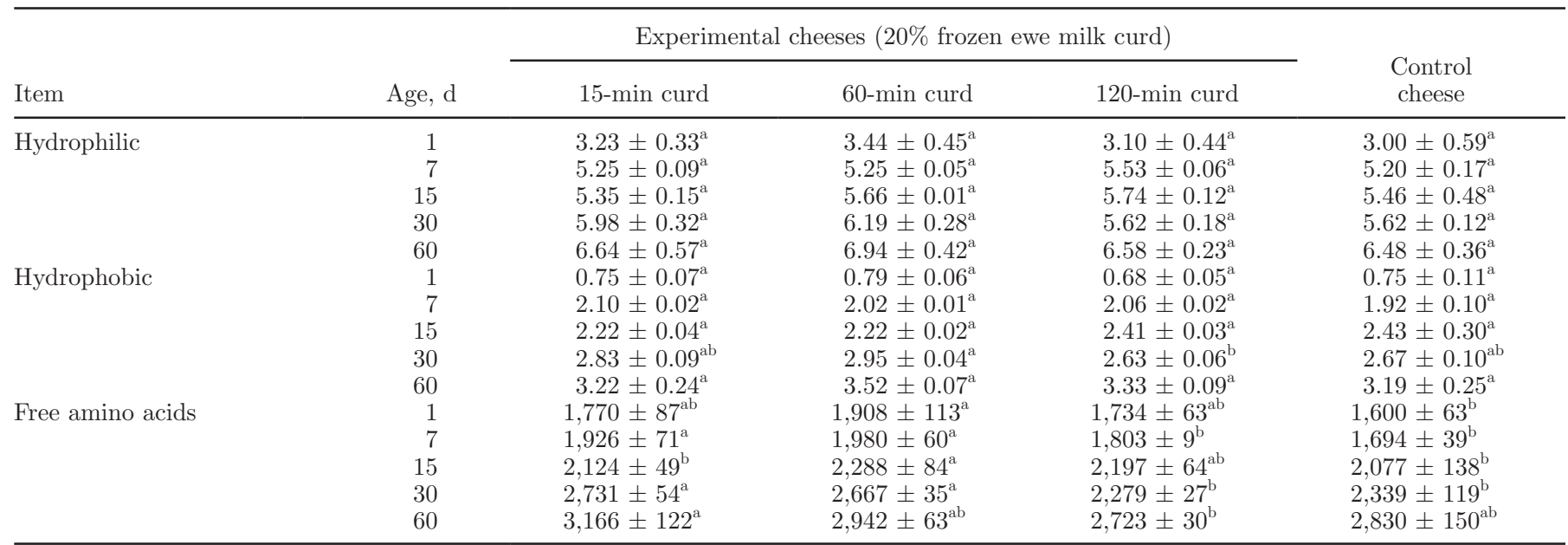

a,b Means in the same row with different superscripts differ $(P<0.05)$.

${ }^{1}$ Mean $\pm \mathrm{SE}(\mathrm{n}=4)$ of duplicate determinations in 2 cheese-making experiments. Peptides are expressed as units of chromatogram area per milligram of cheese DM, and free amino acids as milligrams per kilogram of cheese DM.

accumulate in cheese of high aminopeptidase activity, responsible for a more rapid breakdown of the peptides originating from casein when the intracellular peptidases are released into the cheese matrix (Morgan et al., 1997). However, this was not the case in the present work for cheeses containing frozen ewe milk curd pressed for 15 or $60 \mathrm{~min}$, which showed aminopeptidase activity values similar to the rest (Table 1). Changes in the structure of frozen ewe milk curd, favoring proteolysis and peptidolysis, might be partly responsible for differences in total FAA between cheeses.

\section{FFA and Volatile Compounds}

Significantly $(P<0.05)$ higher levels of acetic acid were found throughout ripening in all experimental cheeses compared with control cheese (Table 4). Acetic acid in pasteurized milk cheeses is mostly derived from LAB metabolism. Differences in acetic acid content cannot be ascribed to lactic culture composition, because the same commercial lactic cultures were used for the manufacture of experimental and control cheeses. Changes in the enzymatic activities of LAB caused by

Table 4. Free fatty acids (FFA) during ripening of experimental Hispánico cheeses manufactured by mixing fresh cow milk curd (80\%) with frozen ewe milk curd (20\%) pressed for 15, 60, or $120 \mathrm{~min}$, and control cheese made from a mixture of cow and ewe milk

\begin{tabular}{|c|c|c|c|c|c|}
\hline \multirow[b]{2}{*}{ FFA $^{1}$} & \multirow[b]{2}{*}{ Age, d } & \multicolumn{3}{|c|}{ Experimental cheese ( $20 \%$ frozen ewe milk curd) } & \multirow{2}{*}{$\begin{array}{c}\text { Control } \\
\text { cheese }\end{array}$} \\
\hline & & 15 -min curd & 60-min curd & 120-min curd & \\
\hline \multirow{3}{*}{ Acetic acid $\left(\mathrm{C}_{2: 0}\right)$} & 15 & $102.4 \pm 3.8^{\mathrm{a}}$ & $100.3 \pm 5.4^{\mathrm{a}}$ & $105.3 \pm 3.6^{\mathrm{a}}$ & $92.7 \pm 7.0^{\mathrm{b}}$ \\
\hline & 30 & $122.2 \pm 9.9^{\mathrm{a}}$ & $112.6 \pm 1.7^{\mathrm{b}}$ & $120.6 \pm 8.8^{\mathrm{a}}$ & $92.9 \pm 4.5^{\mathrm{c}}$ \\
\hline & 60 & $140.5 \pm 4.2^{\mathrm{a}}$ & $140.3 \pm 10.4^{\mathrm{a}}$ & $137.4 \pm 4.2^{\mathrm{a}}$ & $106.5 \pm 1.9^{\mathrm{b}}$ \\
\hline \multirow[t]{3}{*}{ Short-chain FFA $\left(\mathrm{C}_{4: 0^{-}}-\mathrm{C}_{8: 0}\right)$} & 15 & $14.7 \pm 1.8^{\mathrm{a}}$ & $11.1 \pm 0.6^{\mathrm{c}}$ & $11.0 \pm 0.4^{\mathrm{c}}$ & $13.3 \pm 0.4^{\mathrm{b}}$ \\
\hline & 30 & $18.4 \pm 3.1^{\mathrm{a}}$ & $13.9 \pm 2.1^{\mathrm{c}}$ & $13.6 \pm 0.9^{\mathrm{c}}$ & $15.8 \pm 0.6^{\mathrm{b}}$ \\
\hline & 60 & $25.9 \pm 4.6^{\mathrm{a}}$ & $21.1 \pm 3.8^{\mathrm{b}}$ & $19.4 \pm 2.1^{\mathrm{c}}$ & $21.4 \pm 1.7^{\mathrm{b}}$ \\
\hline \multirow{3}{*}{ Medium-chain FFA $\left(\mathrm{C}_{10: 0^{-}} \mathrm{C}_{14: 0}\right)$} & 15 & $82.5 \pm 3.9^{\mathrm{b}}$ & $73.1 \pm 4.0^{\mathrm{c}}$ & $76.1 \pm 3.1^{\mathrm{c}}$ & $89.2 \pm 1.8^{\mathrm{a}}$ \\
\hline & 30 & $91.0 \pm 6.4^{\mathrm{b}}$ & $78.2 \pm 1.3^{\mathrm{d}}$ & $85.5 \pm 3.0^{\mathrm{c}}$ & $97.9 \pm 1.3^{\mathrm{a}}$ \\
\hline & 60 & $108.1 \pm 10.0^{\mathrm{a}}$ & $99.1 \pm 4.3^{\mathrm{b}}$ & $98.8 \pm 0.6^{\mathrm{b}}$ & $110.8 \pm 3.6^{\mathrm{a}}$ \\
\hline \multirow[t]{3}{*}{ Long-chain FFA $\left(\mathrm{C}_{16: 0^{-}} \mathrm{C}_{18: 2}\right)$} & 15 & $435.2 \pm 31.0^{\mathrm{a}}$ & $395.7 \pm 1.4^{\mathrm{b}}$ & $398.7 \pm 7.0^{\mathrm{b}}$ & $443.2 \pm 21.9^{\mathrm{a}}$ \\
\hline & 30 & $462.1 \pm 38.4^{\mathrm{a}}$ & $415.4 \pm 17.8^{\mathrm{b}}$ & $431.4 \pm 4.8^{\mathrm{b}}$ & $453.6 \pm 40.7^{\mathrm{a}}$ \\
\hline & 60 & $524.2 \pm 59.2^{\mathrm{a}}$ & $507.2 \pm 30.0^{\mathrm{ab}}$ & $498.8 \pm 9.2^{\mathrm{b}}$ & $513.7 \pm 55.6^{\mathrm{ab}}$ \\
\hline \multirow[t]{3}{*}{ Total FFA $\left(\mathrm{C}_{4: 0}-\mathrm{C}_{18: 2}\right)$} & 15 & $532.5 \pm 37.7^{\mathrm{a}}$ & $479.9 \pm 2.3^{\mathrm{b}}$ & $485.8 \pm 8.1^{\mathrm{b}}$ & $545.7 \pm 21.5^{\mathrm{a}}$ \\
\hline & 30 & $571.5 \pm 48.9^{\mathrm{a}}$ & $507.5 \pm 21.1^{\mathrm{b}}$ & $530.4 \pm 5.6^{\mathrm{b}}$ & $567.3 \pm 42.2^{\mathrm{a}}$ \\
\hline & 60 & $658.2 \pm 75.8^{\mathrm{a}}$ & $627.4 \pm 38.0^{\mathrm{ab}}$ & $617.0 \pm 11.6^{\mathrm{b}}$ & $645.9 \pm 60.7^{\mathrm{ab}}$ \\
\hline
\end{tabular}

${ }^{\mathrm{a}-\mathrm{d}}$ Means in the same row with different superscripts differ $(P<0.05)$.

${ }^{1}$ Mean $\pm \mathrm{SE}(\mathrm{n}=4)$ of duplicate determinations in 2 cheese-making experiments. Free fatty acids are expressed as milligrams per kilogram of cheese. 
Table 5. Volatile compounds in experimental Hispánico cheeses manufactured by mixing fresh cow milk curd (80\%) with frozen ewe milk curd (20\%) pressed for 15, 60 or 120 min, and in control cheese made from a mixture of cow and ewe milk, showing significant differences between cheeses

\begin{tabular}{|c|c|c|c|c|}
\hline \multirow[b]{2}{*}{ Volatile compound $^{1}$} & \multicolumn{3}{|c|}{ Experimental cheese ( $20 \%$ frozen ewe milk curd) } & \multirow{2}{*}{$\begin{array}{l}\text { Control } \\
\text { cheese }\end{array}$} \\
\hline & 15-min curd & 60 -min curd & 120-min curd & \\
\hline Acetaldehyde & $48.11 \pm 3.55^{\mathrm{b}}$ & $66.07 \pm 2.94^{\mathrm{a}}$ & $64.45 \pm 4.46^{\mathrm{a}}$ & $57.97 \pm 5.05^{\mathrm{ab}}$ \\
\hline 2-Methyl propanal & $0.66 \pm 0.06^{\mathrm{b}}$ & $0.73 \pm 0.06^{\mathrm{b}}$ & $0.70 \pm 0.05^{\mathrm{b}}$ & $1.46 \pm 0.23^{\mathrm{a}}$ \\
\hline 3-Methyl butanal & $3.55 \pm 0.50^{\mathrm{a}}$ & $2.32 \pm 0.63^{\mathrm{b}}$ & $2.18 \pm 0.25^{\mathrm{b}}$ & $4.46 \pm 0.57^{\mathrm{a}}$ \\
\hline 2-Propanone & $262.6 \pm 15.1^{\mathrm{b}}$ & $349.6 \pm 25.7^{\mathrm{a}}$ & $328.5 \pm 18.0^{\mathrm{ab}}$ & $395.3 \pm 30.0^{\mathrm{a}}$ \\
\hline 2-Butanone & $30.11 \pm 1.53^{\mathrm{b}}$ & $37.82 \pm 2.54^{\mathrm{ab}}$ & $43.71 \pm 6.01^{\mathrm{a}}$ & $39.61 \pm 3.36^{\mathrm{ab}}$ \\
\hline 2,3-Butanedione & $514.3 \pm 29.7^{\mathrm{a}}$ & $432.3 \pm 18.3^{\mathrm{ab}}$ & $389.3 \pm 15.0^{\mathrm{ab}}$ & $327.9 \pm 17.3^{\mathrm{b}}$ \\
\hline 2-Pentanone & $9.31 \pm 0.71^{\mathrm{b}}$ & $12.20 \pm 0.90^{\mathrm{ab}}$ & $11.36 \pm 0.96^{\mathrm{ab}}$ & $13.00 \pm 0.88^{\mathrm{a}}$ \\
\hline 2-Nonanone & $5.28 \pm 0.61^{\mathrm{ab}}$ & $4.49 \pm 0.27^{\mathrm{ab}}$ & $4.07 \pm 0.24^{\mathrm{b}}$ & $5.87 \pm 0.67^{\mathrm{a}}$ \\
\hline 2,3 -Pentanedione & $10.09 \pm 1.16^{\mathrm{ab}}$ & $7.40 \pm 0.84^{\mathrm{c}}$ & $9.02 \pm 0.30^{\mathrm{bc}}$ & $10.99 \pm 0.69^{\mathrm{a}}$ \\
\hline 2-Hydroxy-3-pentanone & $1.33 \pm 0.33^{\mathrm{a}}$ & $0.55 \pm 0.11^{\mathrm{b}}$ & $1.19 \pm 0.18^{\mathrm{a}}$ & $1.00 \pm 0.13^{\mathrm{ab}}$ \\
\hline 3 -Hydroxy-2-pentanone & $0.94 \pm 0.23^{\mathrm{a}}$ & $0.40 \pm 0.10^{\mathrm{b}}$ & $0.76 \pm 0.14^{\mathrm{ab}}$ & $0.79 \pm 0.14^{\mathrm{ab}}$ \\
\hline Ethanol & $15,067 \pm 527^{\mathrm{b}}$ & $17,612 \pm 874^{\mathrm{a}}$ & $16,783 \pm 840^{\mathrm{ab}}$ & $16,564 \pm 732^{\mathrm{ab}}$ \\
\hline 1-Propanol & $3.93 \pm 0.24^{\mathrm{b}}$ & $4.65 \pm 0.28^{\mathrm{ab}}$ & $8.63 \pm 1.36^{\mathrm{a}}$ & $7.55 \pm 0.77^{\mathrm{ab}}$ \\
\hline 2-Butanol & $4.87 \pm 1.34^{\mathrm{b}}$ & $5.47 \pm 1.27^{\mathrm{b}}$ & $9.86 \pm 2.50^{\mathrm{a}}$ & $7.02 \pm 1.48^{\mathrm{ab}}$ \\
\hline 2-Pentanol & $0.20 \pm 0.04^{\mathrm{b}}$ & $0.18 \pm 0.05^{\mathrm{b}}$ & $0.37 \pm 0.08^{\mathrm{a}}$ & $0.09 \pm 0.03^{\mathrm{c}}$ \\
\hline 1-Octanol & $0.81 \pm 0.05^{\mathrm{b}}$ & $0.96 \pm 0.05^{\mathrm{ab}}$ & $1.09 \pm 0.08^{\mathrm{a}}$ & $1.02 \pm 0.13^{\mathrm{ab}}$ \\
\hline 2-Methyl-1-propanol & $1.18 \pm 0.07^{\mathrm{b}}$ & $1.30 \pm 0.09^{\mathrm{b}}$ & $1.27 \pm 0.05^{\mathrm{b}}$ & $1.97 \pm 0.18^{\mathrm{a}}$ \\
\hline 3-Methyl-1-butanol & $1.83 \pm 0.33^{\mathrm{b}}$ & $2.27 \pm 0.27^{\mathrm{b}}$ & $2.30 \pm 0.27^{\mathrm{b}}$ & $3.85 \pm 0.42^{\mathrm{a}}$ \\
\hline Methyl acetate & $2.75 \pm 0.13^{\mathrm{b}}$ & $5.10 \pm 1.25^{\mathrm{a}}$ & $3.79 \pm 0.61^{\mathrm{ab}}$ & $4.13 \pm 0.57^{\mathrm{ab}}$ \\
\hline Ethyl acetate & $7.90 \pm 0.36^{\mathrm{b}}$ & $11.06 \pm 0.81^{\mathrm{a}}$ & $10.61 \pm 0.72^{\mathrm{a}}$ & $11.41 \pm 0.94^{\mathrm{a}}$ \\
\hline Dimethyl sulfide & $6.48 \pm 1.09^{\mathrm{b}}$ & $9.91 \pm 0.93^{\mathrm{ab}}$ & $11.15 \pm 1.64^{\mathrm{a}}$ & $10.05 \pm 1.00^{\mathrm{a}}$ \\
\hline
\end{tabular}

${ }^{\mathrm{a}-\mathrm{c}}$ Means in the same row with different superscripts differ $(P<0.05)$.

${ }^{1}$ Mean $\pm \mathrm{SE}(\mathrm{n}=12)$ of duplicate determinations on 15 -, 30 -, and 60 -d-old cheeses in 2 experiments. Volatile compounds are expressed as relative abundances to internal standard cyclohexanone.

freezing (Casla et al., 1995) could be responsible for the observed differences in acetic acid content.

Short-chain FFA were at higher levels in experimental cheese containing frozen ewe milk curd pressed for 15 min than in the other cheeses (Table 4). Curd frozen after pressing for only $15 \mathrm{~min}$ had a higher $\mathrm{pH}$ at freezing (mean $\mathrm{pH}$ value, 6.50) than curd pressed for $60 \mathrm{~min}$ (mean $\mathrm{pH}$ value, 6.38) or $120 \mathrm{~min}$ (mean $\mathrm{pH}$ value, 6.24 ), which could have favored the activity of residual ewe milk lipase activity during frozen storage. Levels of medium-chain and long-chain FFA in experimental cheese containing frozen ewe milk curd pressed for 15 min were higher than in the other experimental cheeses, and similar to those of control cheese (Table 4). After $60 \mathrm{~d}$ of ripening, total FFA were significantly higher in experimental cheese containing ewe milk curd pressed for $15 \mathrm{~min}$ and in control cheese compared with the other cheeses, although the differences were of limited practical significance. Frozen storage of Cabrales cheese for up to 8 mo before ripening did not affect the level of lipolysis (Alonso et al., 1987). Of 4 goat milk cheeses investigated, only a soft cheese with surface flora exhibited enhanced lipolysis when frozen for 4 mo before ripening (Martín Hernández et al., 1990).

Lactic acid bacteria enzymes such as proteinases, peptidases, amino acid catabolic enzymes, and esterases transform milk constituents retained in the curd into cheese flavor compounds and aroma precursors (Engels and Visser, 1996; Lane and Fox, 1997; Smit et al., 2005). Volatile compounds derived from the catabolism of free amino acids, including ammonia, amines, aldehydes, phenols, indole, and alcohols, together with the FFA derived from the hydrolysis of triglycerides and the esters resulting from their reaction with alcohols, contribute to cheese flavor (McSweeney and Sousa, 2000).

In the volatile fraction of Hispánico cheese, 68 compounds ( 7 aldehydes, 10 ketones, 17 alcohols, 5 esters, 9 hydrocarbons, 9 benzene compounds, and 11 miscellaneous compounds) were identified in the present work. Twenty-one volatile compounds showed significant $(P$ $<0.05$ ) differences between cheeses (Table 5). In most cases, their levels hardly varied with cheese age. For this reason, the results presented in Table 5 are the pooled values for 15-, 30- and 60-d-old cheeses.

Acetaldehyde, produced through lactose metabolism by LAB or derived from threonine breakdown (Engels et al., 1997), was at higher levels in experimental cheeses containing ewe milk curds pressed for 60 or 120 min. Differences in acetaldehyde levels between cheeses cannot be ascribed to the latter pathway, because differences in their threonine content were irrelevant. On the contrary, the branched-chain aldehydes 2-methyl propanal and 3-methyl butanal reached their highest 
Table 6. Textural characteristics during ripening of experimental Hispánico cheeses manufactured by mixing fresh cow milk curd (80\%) with frozen ewe milk curd (20\%) pressed for 15, 60, or 120 min, and control cheese made from a mixture of cow and ewe milk ${ }^{1}$

\begin{tabular}{|c|c|c|c|c|c|}
\hline \multirow[b]{2}{*}{ Characteristic } & \multirow[b]{2}{*}{ Age, d } & \multicolumn{3}{|c|}{ Experimental cheese ( $20 \%$ frozen ewe milk curd) } & \multirow{2}{*}{$\begin{array}{l}\text { Control } \\
\text { cheese }\end{array}$} \\
\hline & & 15-min curd & 60-min curd & 120-min curd & \\
\hline \multirow{2}{*}{ Fracturability, N } & 30 & $28.32 \pm 1.68^{\mathrm{a}}$ & $27.85 \pm 1.80^{\mathrm{a}}$ & $25.67 \pm 1.92^{\mathrm{a}}$ & $27.61 \pm 2.71^{\mathrm{a}}$ \\
\hline & 60 & $44.80 \pm 2.29^{\mathrm{a}}$ & $43.98 \pm 2.77^{\mathrm{a}}$ & $43.07 \pm 2.22^{\mathrm{a}}$ & $40.45 \pm 3.55^{\mathrm{a}}$ \\
\hline \multirow[t]{2}{*}{ Hardness, J } & 15 & $0.249 \pm 0.023^{\mathrm{a}}$ & $0.235 \pm 0.021^{\mathrm{a}}$ & $0.229 \pm 0.024^{\mathrm{a}}$ & $0.215 \pm 0.014^{\mathrm{a}}$ \\
\hline & 30 & $0.306 \pm 0.017^{\mathrm{a}}$ & $0.305 \pm 0.025^{\mathrm{a}}$ & $0.292 \pm 0.020^{\mathrm{a}}$ & $0.328 \pm 0.037^{\mathrm{a}}$ \\
\hline \multirow{2}{*}{ Elasticity, $\mathrm{N} / \mathrm{mm}^{2}$} & 30 & $0.503 \pm 0.064^{\mathrm{a}}$ & $0.604 \pm 0.067^{\mathrm{a}}$ & $0.574 \pm 0.060^{\mathrm{a}}$ & $0.670 \pm 0.150^{\circ}$ \\
\hline & 60 & $1.134 \pm 0.066^{\mathrm{a}}$ & $1.384 \pm 0.135^{\mathrm{a}}$ & $1.302 \pm 0.092^{\mathrm{a}}$ & $1.307 \pm 0.214^{\mathrm{a}}$ \\
\hline
\end{tabular}

${ }^{\mathrm{a}}$ Means in the same row with different superscripts differ $(P<0.05)$.

${ }^{1}$ Mean $\pm \operatorname{SE}(n=12)$ of 6 determinations in 2 cheese-making experiments.

values in control cheese, which also showed the highest contents of branched-chain alcohols 2-methyl 1-propanol and 3-methyl 1-butanol. Regarding ketones, the highest levels of 2,3-butanedione, 2-hydroxy-3-pentanone, and 3-hydroxy-2-pentanone were found in experimental cheese containing ewe milk curd pressed for $15 \mathrm{~min}$; this cheese, on the other hand, exhibited the lowest levels of 2-propanone, 2-butanone, and 2-pentanone. The highest levels of alcohols 1-propanol, 2-butanol, 2-pentanol, and 1-octanol were found in experimental cheese containing ewe milk curd pressed for $120 \mathrm{~min}$. With respect to esters, cheese containing ewe milk curd pressed for 60 min showed the highest values of methyl acetate and ethyl acetate. As indicated above for acetic acid, LAB enzymatic activities may be influenced by freezing (Casla et al., 1995), and changes in the metabolism of LAB present in frozen ewe milk curd might explain the differences observed for the levels of some volatile compounds.

\section{Instrumental Texture}

Fracturability, hardness, and elasticity of cheeses (Table 6) increased significantly $(P<0.05)$ during ripening, most probably because the strengthening effect of moisture loss during ripening predominated over the weakening effect of caseinolysis. A relationship between lower levels of residual $\alpha_{\mathrm{s}}$-casein and a softer cheese texture has been reported for Hispánico cheese (Ávila et al., 2005). In the present work, differences in textural characteristics were statistically nonsignificant $(P>$ 0.05 ), probably because the differences in proteolysis between cheeses at the same stage of ripening were negligible.

Researchers working with frozen unsalted or salted curd or cheese (Alichanidis et al., 1981; Fontecha et al., 1996; Sendra et al., 1999) or with frozen ripe cheese (Tejada et al., 2000) reported a crumbly, grainy, or softer texture, or even crevices, for experimental cheeses compared with control cheese. In the present work, no such texture defects were observed.

\section{Sensory Flavor Characteristics}

Flavor intensity scores of all cheeses increased with ripening time, but no clear trend for flavor quality scores was recorded as cheeses aged (Table 7). Umami taste scores increased with ripening time (Table 7), most probably because of the accumulation of water-soluble peptides and FAA in cheeses (Table 3). A significant increase in Hispánico cheese umami taste scores with ripening time had been previously reported (Ávila et al., 2006b). In the present work, significant $(P<$ 0.001 ) correlations were found for pooled data from 15-, 30- and 60-d-old cheeses between hydrophilic peptides and flavor intensity $\left(\mathrm{r}^{2}=0.673\right)$ or umami taste $\left(\mathrm{r}^{2}=\right.$ $0.651)$, between FAA and flavor intensity $\left(\mathrm{r}^{2}=0.666\right)$ or umami taste $\left(\mathrm{r}^{2}=0.689\right)$, and between flavor intensity and umami taste $\left(\mathrm{r}^{2}=0.700\right)$.

Bitter taste scores also increased with ripening time (Table 7), in agreement with data previously reported (Ávila et al., 2006b), a fact which might have negatively affected the flavor quality of cheeses. A significant $(P$ $<0.05)$ correlation was found for pooled data from 15-, 30- and 60-d-old cheeses between the hydrophobic peptides:hydrophilic peptides ratio and bitter taste $\left(\mathrm{r}^{2}\right.$ $=0.422$ ), but correlations between this ratio and flavor quality $\left(\mathrm{r}^{2}=0.061\right)$ or between bitter taste and flavor quality $\left(r^{2}=0.126\right)$ were nonsignificant.

No significant differences between cheeses were found in the present work for flavor intensity or quality, and none of the attributes acid taste, bitter taste, salty taste, sweet taste, or umami taste varied significantly between cheeses. Sweet taste scores remained below 0.50 (on a 10-point scale) during ripening of all cheeses (data not shown). Statistically significant differences in 
Table 7. Sensory characteristics during ripening of experimental Hispánico cheeses manufactured by mixing fresh cow milk curd (80\%) with frozen ewe milk curd $(20 \%)$ pressed for 15,60 , or 120 min, and control cheese made from a mixture of cow and ewe milk ${ }^{1}$

\begin{tabular}{|c|c|c|c|c|c|}
\hline \multirow[b]{2}{*}{ Characteristic } & \multirow[b]{2}{*}{ Age, d } & \multicolumn{3}{|c|}{ Experimental cheese ( $20 \%$ frozen ewe milk curd) } & \multirow{2}{*}{$\begin{array}{l}\text { Control } \\
\text { cheese }\end{array}$} \\
\hline & & 15-min curd & 60-min curd & $120-\min$ curd & \\
\hline Flavor intensity & 60 & $6.18 \pm 0.09^{\mathrm{a}}$ & $6.26 \pm 0.01^{\mathrm{a}}$ & $6.34 \pm 0.23^{\mathrm{a}}$ & $6.34 \pm 0.10^{\mathrm{a}}$ \\
\hline \multirow{2}{*}{ Flavor quality } & 15 & $5.77 \pm 0.37^{\mathrm{a}}$ & $5.69 \pm 0.11^{\mathrm{a}}$ & $5.48 \pm 0.26^{\mathrm{a}}$ & $5.47 \pm 0.39^{\mathrm{a}}$ \\
\hline & 30 & $5.85 \pm 0.11^{\mathrm{a}}$ & $5.71 \pm 0.35^{\mathrm{a}}$ & $5.71 \pm 0.11^{\mathrm{a}}$ & $5.74 \pm 0.31^{\mathrm{a}}$ \\
\hline \multirow{2}{*}{ Acid taste } & 30 & $3.21 \pm 0.02^{\mathrm{a}}$ & $3.10 \pm 0.45^{\mathrm{a}}$ & $3.31 \pm 0.51^{\mathrm{a}}$ & $3.02 \pm 0.61^{\mathrm{a}}$ \\
\hline & 60 & $3.13 \pm 0.36^{\mathrm{a}}$ & $3.39 \pm 0.06^{\mathrm{a}}$ & $3.47 \pm 0.22^{\mathrm{a}}$ & $3.23 \pm 0.04^{\mathrm{a}}$ \\
\hline \multirow[t]{3}{*}{ Bitter taste } & 15 & $1.67 \pm 0.19^{\mathrm{a}}$ & $1.69 \pm 0.12^{\mathrm{a}}$ & $1.49 \pm 0.05^{\mathrm{a}}$ & $1.52 \pm 0.19^{\mathrm{a}}$ \\
\hline & 30 & $1.51 \pm 0.02^{\mathrm{a}}$ & $1.93 \pm 0.18^{\mathrm{a}}$ & $1.63 \pm 0.29^{\mathrm{a}}$ & $1.60 \pm 0.25^{\mathrm{a}}$ \\
\hline & 60 & $1.98 \pm 0.44^{\mathrm{a}}$ & $2.00 \pm 0.17^{\mathrm{a}}$ & $2.10 \pm 0.12^{\mathrm{a}}$ & $2.02 \pm 0.11^{\mathrm{a}}$ \\
\hline \multirow{2}{*}{ Salty taste } & 15 & $2.11 \pm 0.01^{\mathrm{a}}$ & $2.10 \pm 0.01^{\mathrm{a}}$ & $1.99 \pm 0.16^{\mathrm{a}}$ & $2.08 \pm 0.10^{\mathrm{a}}$ \\
\hline & 30 & $1.92 \pm 0.11^{\mathrm{a}}$ & $2.01 \pm 0.21^{\mathrm{a}}$ & $2.03 \pm 0.25^{\mathrm{a}}$ & $1.95 \pm 0.34^{\mathrm{a}}$ \\
\hline
\end{tabular}

${ }^{a}$ Means in the same row with different superscripts differ $(P<0.05)$.

${ }^{1}$ Mean $\pm \mathrm{SE}(\mathrm{n}=2)$ of 2 cheese-making experiments, evaluated by 14 trained panelists on a $0-10$ point scale.

the concentrations of flavor compounds may not suffice to significantly influence cheese flavor characteristics. A 5.5-fold increase in FAA concentration in 50-d-old Hispánico cheese resulted in a significant increase (although only 1.2 -fold) of its flavor intensity, whereas a 3.4 -fold increase in FAA concentration had no significant effect (Garde et al., 2002b). Considerable increases in the concentrations of some potent odorants (2.5-, 4.2-, 15.6-, 5.6-, 2.5- and 4.3-fold, respectively, for 3-methyl butanal, 2,3-butanedione, 2,3-pentanedione, 3-hydroxy2-butanone, ethyl acetate, and ethyl butanoate) did not significantly affect the intensity of Hispánico cheese odor or aroma (Ávila et al., 2006a). Because of the complexity of cheese flavor and the limitations of both instrumental techniques and human tasting panels, it is not an easy task to correlate the concentration of volatile compounds with sensory characteristics (Carbonell et al., 2002). Taking into account the reported magnitudes of increase in compound concentrations needed for a significant effect on flavor characteristics, the absence of significant differences between cheese flavor characteristics observed in the present work can be plausibly explained by the minor differences found for compound concentrations.

\section{CONCLUSIONS}

When Hispánico cheese was manufactured by mixing thawed ewe milk curd pressed for 15, 60, or $120 \mathrm{~min}$ with fresh cow milk curd, and compared with control cheese made from a mixture of pasteurized cow and ewe milk, no significant differences were found for LAB counts, DM content, hydrophilic peptides, 47 out of 68 volatile compounds, instrumental texture, or sensory flavor characteristics. On the other hand, minor differences between cheeses were found for $\mathrm{pH}$ value, aminopeptidase activity, proteolysis (OPA method), hydrophobic peptides, FAA, FFA, and the remaining 21 volatile compounds, which could not be related to the use of frozen ewe milk curd or the pressing time of ewe milk curd before freezing. It may be concluded that the use of frozen ewe milk curd in the manufacture of Hispánico cheese does not alter its characteristics and may serve to overcome seasonal shortage of ewe milk.

\section{ACKNOWLEDGMENTS}

This work was supported by the AGL 2004-06051 project, funded by the Spanish Ministry of Education and Science. The authors thank B. Rodríguez, M. de Paz, and J. Calzada (Departamento de Tecnología de Alimentos, INIA, Madrid, Spain) for their valuable technical assistance.

\section{REFERENCES}

Alichanidis, E., A. Polychroniadou, N. Tzanetakis, and A. Vafopoulou. 1981. Teleme cheese from deep-frozen curd. J. Dairy Sci. 64:732 739.

Alonso, L., M. Juárez, M. Ramos, and P. J. Martín-Alvarez. 1987. Effects of changes during ripening and frozen storage on the physicochemical and sensory characteristics of Cabrales cheese. Int. J. Food Sci. Technol. 22:525-534.

Ávila, M., S. Garde, E. Fernández-García, M. Medina, and M. Nuñez. 2006a. Effect of high pressure treatment and a bacteriocin- 
producing lactic culture on the odor and aroma of Hispánico cheese: Correlation of volatile compounds and sensory analysis. J. Agric. Food Chem. 54:382-389.

Ávila, M., S. Garde, P. Gaya, M. Medina, and M. Nuñez. 2005. Influence of a bacteriocin-producing lactic culture on proteolysis and texture of Hispánico cheese. Int. Dairy J. 15:145-153.

Ávila, M., S. Garde, P. Gaya, M. Medina, and M. Nuñez. 2006b. Effect of high pressure treatment and a bacteriocin-producing lactic culture on the proteolysis, texture and taste of Hispánico cheese. J. Dairy Sci. 89:2882-2893.

Carbonell, M., M. Nuñez, and E. Fernández-García. 2002. Evolution of the volatile compounds of ewes raw milk La Serena cheese during ripening. Correlation with flavor characteristics. Lait 82:683698.

Casla, D., J. Fontecha, R. Gomez, and C. Pelaez. 1995. The effects of freezing and frozen storage of ewes milk cheese on the viability and proteolytic activity of lactococci used as a starter. Z. Lebensm. Unters. Forsch. 200:59-63.

Church, F. C., H. E. Swaisgood, D. H. Porter, and G. L. Catignani. 1983. Spectrophotometric assay using o-phthaldialdehyde for determination of proteolysis in milk and isolated milk proteins. J. Dairy Sci. 66:1219-1227.

De Jong, C., and H. T. Badings. 1990. Determination of free fatty acids in milk and cheese-Procedures for extraction, clean up, and capillary gas-chromatographic analysis. J. High Resol. Chromatogr. 13:94-98.

Engels, W. J. M., R. Dekker, C. De Jong, R. Neeter, and S. Visser. 1997. A comparative study of volatile compounds in the watersoluble fraction of various types of ripened cheese. Int. Dairy J. $7: 255-263$.

Engels, W. J. M., and S. Visser. 1996. Development of cheese flavor from peptides and amino acids by cell-free extracts of Lactococcus lactis ssp. cremoris B78 in a model system. Neth. Milk Dairy J. $50: 3-17$.

Fernández-García, E., M. Carbonell, J. Calzada, and M. Nuñez. 2006. Seasonal variation of the free fatty acids contents of Spanish ovine milk cheeses protected by a designation of origin: A comparative study. Int. Dairy J. 16:252-261.

Fontecha, J., M. Kalab, J. A. Medina, C. Peláez, and M. Juárez. 1996. Effects of freezing and frozen storage on the microstructure and texture of ewe's milk cheese. Z. Lebensm. Unters. Forsch. 203:245-251.

Fontecha, J., C. Peláez, M. Juárez, and M. C. Martín-Hernández. 1994. Effect of freezing and frozen storage on the physicochemical, organoleptic and microbiological characteristics of a semi-hard ewes' milk cheese. J. Dairy Res. 61:133-142.

Garde, S., M. Ávila, P. Gaya, M. Medina, and M. Nuñez. 2006. Proteolysis of Hispánico cheese manufactured using lacticin 481-producing Lactococcus lactis ssp. lactis INIA 639. J. Dairy Sci. 89:840-849

Garde, S., M. Carbonell, E. Fernández-García, M. Medina, and M. Nuñez. 2002a. Volatile compounds in Hispánico cheese manufactured using a mesophilic starter, a thermophilic starter and bacteriocin-producing Lactococcus lactis ssp. lactis INIA 415. J. Agric. Food Chem. 50:6752-6757.
Garde, S., P. Gaya, E. Fernández-García, M. Medina, and M. Nuñez. 2003. Proteolysis and volatile compounds in Hispánico cheese manufactured with a mesophilic starter, a thermophilic starter, and calcium alginate-nisin microparticles. J. Dairy Sci. 86:30383047 .

Garde, S., J. Tomillo, P. Gaya, M. Medina, and M. Nuñez. 2002b. Proteolysis in Hispánico cheese manufactured using a mesophilic starter, a thermophilic adjunct culture and bacteriocin-producing Lactococcus lactis ssp. lactis INIA 415 adjunct culture. J. Agric. Food Chem. 50:3479-3485.

Gava, P., M. Medina, M. A. Rodríguez-Marín, and M. Nuñez. 1990. Accelerated ripening of ewes' milk Manchego cheese: The effect of elevated ripening temperatures. J. Dairy Sci. 73:26-32.

Gómez, M. J., S. Garde, P. Gaya, M. Medina, and M. Nuñez. 1997. Relationship between levels of hydrophobic peptides and bitterness in cheese made from pasteurized and raw milk. J. Dairy Res. 64:289-297.

Krause, I., A. Bockhardt, H. Neckermann, T. Henle, and H. Klostermeyer. 1995. Simultaneous determination of amino acids and biogenic amines by reversed-phase high-performance liquid chromatography of the dabsyl derivatives. J. Chromatogr. A 715:67-79.

Lane, C. N., and P. F. Fox. 1997. Role of starter enzymes during ripening of Cheddar cheese made from pasteurised milk under controlled microbiological conditions. Int. Dairy J. 7:55-63.

Lau, K. Y., D. M. Barbano, and R. R. Rasmussen. 1991. Influence of pasteurization of milk on protein breakdown in Cheddar cheese during aging. J. Dairy Sci. 74:727-740.

Martín-Hernández, C., M. Juárez, M. Ramos, and P. Martín-Alvarez. 1990. Effects of freezing and frozen storage on the physicochemical and sensory characteristics of four types of goat's cheese. Z. Lebensm. Unters. Forsch. 190:325-330.

McSweeney, P. L. H., and M. J. Sousa. 2000. Biochemical pathways for the production of flavor compounds in cheeses during ripening: A review. Lait 80:293-324.

Morgan, S., R. P. Ross, and C. Hill. 1997. Increasing starter cell lysis in Cheddar cheese using a bacteriocin-producing adjunct. J. Dairy Sci. 80:1-10.

Sendra, E., M. Mor-Mur, R. Pla, and B. Guamis. 1999. Evaluation of freezing pressed curd for delayed ripening of semi-hard ovine cheese. Milchwissenschaft 54:550-553.

Sendra, E., J. Saldo, M. Mor-Mur, R. Pla, and B. Guamis. 2002. Long term frozen storage of Manchego curds. Milchwissenshaft 57:635-637.

Smit, G., B. Smit, and W. Engels. 2005. Flavor formation by lactic acid bacteria and biochemical flavor profiling of cheese products. FEMS Microbiol. Rev. 29:591-610.

Tejada, L., R. Gómez, M. Vioque, E. Sánchez, C. Mata, and J. Fernández-Salguero. 2000. Effect of freezing and frozen storage on the sensorial characteristics of Los Pedroches, a Spanish ewe cheese. J. Sens. Stud. 15:251-262.

Tejada, L., E. Sánchez, R. Gómez, M. Vioque, and J. FernándezSalguero. 2002. Effect of freezing and frozen storage on chemical and microbiological characteristics in sheep milk cheese. J. Food Sci. $67: 126-129$. 